\title{
RESEARCH OF THE LEVEL OF THE INNOVATIVE DEVELOPMENT OF THE MACHINE BUILDING ENTERPRISES OF UKRAINE IN KHARKOV REGION
}

\author{
Kateryna KOLIEDINA ${ }^{1}$, \\ Kharkov National University of Civil Engineering and Architecture, Ukraine
}

\begin{abstract}
In today's world of the science and new technologies development all the countries including Ukraine are entrusted with a task of refocusing on the innovative way of evolution. The level of innovativeness of the country depends on the development of enterprises in this regard since exactly the industrial enterprises are able to induce the innovative process and be a multiplier of other economic sectors. Thus it is expedient to re-equip the industry of the state and encourage exactly the high-tech branches thereof. In this regard the goal of this paper is to explore and assess the influence of the criteria of innovative activity of the industrial enterprises on the level of the innovative development thereof. To reach the mentioned goal the criteria of innovative activity of the leading machine building enterprises of Ukraine in Kharkov region are chosen as the object of research. The studied enterprises are innovatively active in Kharkov region according to the criteria of the work thereof. The following criteria of innovative activity of the enterprises are chosen for analysis: the volume of the sold innovative products; the charges for innovation; the research intensity of the innovative products; the share of the studied enterprises in the total volume of the products sold in this region; the quantity of the new technological processes; the quantity of the new innovative kinds of products. The chosen criteria are important for enterprise in relation to the innovative activity and in case of changes have a substantial influence on its development and stability.

Methodology. To research the level of innovative development of the machine building enterprises of Ukraine in Kharkov region the author prop:

1) Formation of the matrix of the basic data;

2) Standardization of the basic data;

3) Differentiation of the characteristics on inciters and disincentives;

4) Construction of the etalon;

5) Determination of the distance between the objects and etalon;

6) Calculation of the criteria of the level of development;

7) Preparation of the rating of the enterprises depending on the level of innovative development.

Results. According to the results of the conducted taxonomic analysis of the certain machine building enterprises of Kharkov region (Ukraine) the criteria of the level of development of the studied enterprises ranges from 0,524 to 0,878 . The obtained result evidences that although the enterprises declare the orientation on the innovative development, actually not all of the studied enterprises are innovatively active at all the criteria. However the rate of the taxonomic criteria of the most of them is inclined to one, that confirms the orientation thereof on the innovative way of development. Value/originality. The data obtained in result of the calculation and analysis encourages the better understanding of the synergies between the criteria of the innovative activity of the enterprises and the level of the innovative development thereof. This allows the enterprises to correct their innovative activity depending on the current situation and take the effective management decisions directed on the way of innovative development in future.
\end{abstract}

Key words: enterprise, innovation, innovative activity, innovative development, taxonomic analysis.

JEL Classification: C15, D2, O31

\footnotetext{
Corresponding author:

${ }^{1}$ Department Finance and Credit, Kharkov National University of Civil Engineering and Architecture.

E-mail: koliedinakateryna@gmail.com
} 


\section{Introduction}

In today's world of the science and new technologies development all the countries including Ukraine are entrusted with a task of refocusing on the innovative way of evolution. The level of innovativeness of the country depends on the development of enterprises in this regard since exactly the industrial enterprises are able to induce the innovative process and be a multiplier of other economic sectors. Thus it is expedient to re-equip the industry of the state and encourage exactly the high-tech branches thereof (Senichkina, 2014, p. 71-76). In this regard research and assessment of the influence of the criteria of innovative activity of the industrial enterprises on the level of the innovative development thereof become more important.

The works of famous foreign and domestic scientists are dedicated to the issue of the present condition of the innovative activity of Ukraine and its enterprises, still these categories are not statical instead they constantly change causing the necessity of the regular analysis for revealing the main tendencies. In this regard the goal of this paper is research of the influence of the level of the machine building enterprises of Kharkov region using the method of the taxonomic analysis.

\section{Algorithm of conducting the taxonomic analysis}

The present conditions demand the enterprises to form the effective strategy of the development which should be based on innovative integral part, still it is impossible without the assessment of the results of the enterprises' activity. Therefore the analysis of the innovative activity and the revelation of the reserves for elevation of the level of innovative development thereof become the toppriority question for the enterprises. To reach the mentioned goal we proposed to use the taxonomic method of the assessment of the influence of the criteria of innovative activity of the machine building enterprises on the criteria of innovative development thereof.

This method of analysis foresees the existence of the etalon of reaching the indicator values and determination of the distance between the actual and etalon level, that results in composition of the taxonomic marker of the development (Ponomarenko \& Malyarets, 2009, p. 432), the computation algorithm of the latter is presented at pic. 1 .

\section{Choice of the criteria for formation of the matrix of the basic data}

On the first stage of analysis of the innovative development of enterprise it is necessary to form the matrix of the basic data which is as follows:

$$
\mathbf{X}=\left(\begin{array}{ccc}
x_{11} & \ldots & x_{1 m} \\
\ldots & \ldots & \ldots \\
x_{n 1} & \ldots & x_{n m}
\end{array}\right)
$$

where $n$ - the quantity of the objects which are used;

$m$ - the quantity of the features;

$x_{i j}$ - the value of indicator $\mathrm{j}$ for the object $\mathrm{i}$.

The following leading machine building enterprises of Ukraine in Kharkov region became the objects of research: State Enterprise Plant "Electrotyazhmash", Public Joint Stock Company Yuzhcable Works, Public Joint-Stock Company "Kharkov Machine-Building Plant "Svet Shakhtyora", Public Joint-Stock Company "Kharkov Bearing Plant", Public Joint-Stock Company "Electromashina", "Turboatom" Public Joint Stock Company, Public Joint-Stock Company "Kharkov Trac S. Ordzhonikidze Plant", State Research and Development Enterprise "Obiedinenie Communar", Public Stock Company Frunze Plant and State Enterprise "Kharkov Machine Building Plant "FED". Theses enterprises are innovatively active in Kharkov region according to the criteria of the work thereof.

We also note that the chosen criteria are important for the enterprise from the point of the innovative activity and in case of changes have substantial influence on the development and stability thereof.

Table 1 contains the values of the indicator values of the innovative activity of the number of the machinery enterprises of Kharkov region which implement innovations (information of the Report of the State Statistics Committee of Ukraine, 2014).

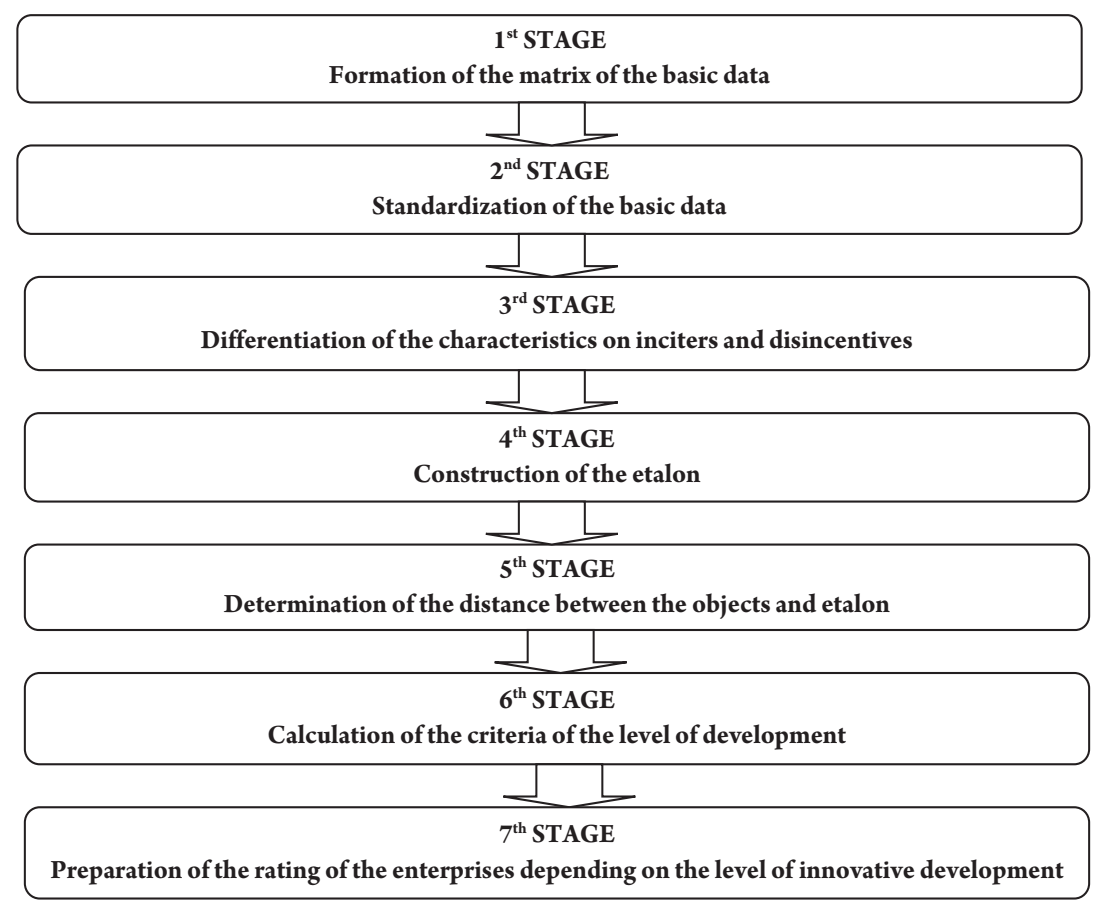

Pic. 1. Algorithm of the determination of the indicator of the level of innovative development of the enterprise 
Table 1

Criteria of innovative activity of the enterprises of the machine building industry of Kharkov region in year 2014

\begin{tabular}{|c|c|c|c|c|c|c|}
\hline Enterprise & $\mathrm{x}_{1}$ & $\mathrm{x}_{2}$ & $\mathrm{x}_{3}$ & $\mathrm{x}_{4}$ & $\mathrm{x}_{5}$ & $\mathrm{x}_{6}$ \\
\hline $\begin{array}{l}\text { Public Joint-Stock Company "Kharkov Machine-Building Plant } \\
\text { "Svet Shakhtyora }\end{array}$ & 28829,2 & 206,7 & 0,00352 & 0,97 & 1 & 2 \\
\hline State Enterprise Plant "Electrotyazhmash" & 603180,5 & 18590,8 & 0,00001 & 20,29 & 4 & 12 \\
\hline Public Joint Stock Company Yuzhcable Works & 47887,7 & 91155,6 & 1,10031 & 1,61 & 2 & 2 \\
\hline \multicolumn{7}{|l|}{ Public Joint-Stock Company "Electromashina" } \\
\hline 20335,6 & 6535,0 & 0,00647 & 0,68 & 3 & 1 & \\
\hline Public Stock Company Frunze Plant & 57710,9 & 8804,6 & 0,00001 & 1,94 & 1 & 1 \\
\hline $\begin{array}{l}\text { Public Joint-Stock Company "Kharkov Trac S. Ordzhonikidze } \\
\text { Plant" }\end{array}$ & 198492,8 & 2987,9 & 0,01348 & 6,68 & 1 & 1 \\
\hline "Turboatom" Public Joint Stock Company & 745149,5 & 7325,1 & 0,00505 & 25,07 & 5 & 4 \\
\hline \multicolumn{7}{|l|}{ Public Joint-Stock Company "Kharkov Bearing Plant" } \\
\hline 11518,4 & 32853,8 & 0,12675 & 0,39 & 25 & 8 & \\
\hline $\begin{array}{l}\text { State Research and Development Enterprise "Obiedinenie } \\
\text { Communar" }\end{array}$ & 47810,4 & 1638,3 & 0,00984 & 1,61 & 2 & 3 \\
\hline State Enterprise "Kharkov Machine Building Plant "FED" & 3073,4 & 1900,6 & 0,00001 & 0,10 & 8 & 1 \\
\hline
\end{tabular}

where $\mathrm{x}_{1}$ - volume of the sold innovative products, thousand, hryvnias; $\mathrm{x}_{2}$ - expenses for innovation, thousand, hryvnias;

$\mathrm{x}_{3}$ - knowledge content of the innovative products, hryvnias/hryvnias;

$\mathrm{x}_{4}$ - percent of the studied enterprises in the total volume of the products sold in the region, $\%$;

$\mathrm{x}_{5}$ - quantity of the new technical processes, items;

$\mathrm{x}_{6}$ - quantity of the new innovative kinds of products, names.

\section{Construction of the etalon point}

Since the chosen indicators are non-uniform the further calculation requires the standardization procedure. This will allow all units of measurement to become the nondimensional values and thus to smooth the value of the characteristic. The following formula is used therefore:

$z_{i}=\frac{x_{i}}{\bar{x}}$

where $z_{i}$-standard value of $j$-th indicator for $i$-th object; $x_{i}$ - arithmetical average of $i$-th characteristic.

The results of the standardization of the basic data are presented in table 2 .

Table 2

Matrix of the standardize data

\begin{tabular}{|c|c|c|c|c|c|}
\hline $\mathrm{x}_{1}$ & $\mathrm{x}_{2}$ & $\mathrm{x}_{3}$ & $\mathrm{x}_{4}$ & $\mathrm{x}_{5}$ & $\mathrm{x}_{6}$ \\
\hline 0,163432 & 0,012018 & 0,027822 & 0,163432 & 0,192308 & 0,571429 \\
\hline 3,419413 & 1,080871 & 0,000118 & 3,419413 & 0,769231 & 3,428571 \\
\hline 0,271474 & 5,299793 & 8,694921 & 0,271474 & 0,384615 & 0,571429 \\
\hline 0,115282 & 0,379945 & 0,051139 & 0,115282 & 0,576923 & 0,285714 \\
\hline 0,327161 & 0,5119 & 6,84642 & 0,327161 & 0,192308 & 0,285714 \\
\hline 1,12525 & 0,173717 & 0,106495 & 1,12525 & 0,192308 & 0,285714 \\
\hline 4,224231 & 0,425882 & 0,039927 & 4,224231 & 0,961538 & 1,142857 \\
\hline 0,065297 & 1,910122 & 1,001641 & 0,065297 & 4,807692 & 2,285714 \\
\hline 0,271036 & 0,095251 & 0,077766 & 0,271036 & 0,384615 & 0,857143 \\
\hline 0,017423 & 0,110501 & 0,000103 & 0,017423 & 1,538462 & 0,285714 \\
\hline
\end{tabular}

The following step is differentiation of all the variables on inciters and disincentives. Characteristics which positively influence on the innovative development belong to the inciters, characteristics hindering the development belong to the disincentives.

$$
\left\{\begin{array}{l}
x_{o i}=\max x_{i j}-\text { inciter } \\
x_{o i}=\min x_{i j}-\text { disincentive }
\end{array}\right.
$$

In our case all the indicators (volume of the sold innovative products, expenses for innovation, knowledge content of the innovative products, percent of the studied enterprises in the total volume of the products sold in the region, quantity of the new technical processes and the new innovative kinds of products) are inciters since no one of them hinders the innovative development of the enterprise, and instead, optimizes it. Therefore for construction of the etalon value we choose $x_{o i}=\max x_{i j}$ for all the indicators.

According to table 3 vector-etalon for the innovatively active enterprises of the machine building sector of Kharkov region has the following coordinates:

$$
\begin{aligned}
& P_{o}=(4,224231 ; 5,299793 ; 8,694921 ; \\
& 4,224231 ; 4,807692 ; 3,428571)
\end{aligned}
$$

\section{Calculation of the criteria}

\section{of innovative development of the enterprises}

On the fifth stage of taxonomic analysis the calculation of the distance between the separate indicators characterizing the level of the innovative development of enterprise and the etalon point is conducted. Euclidean distance is determined according to the following formula:

Table 3

Value of the etalon point

\begin{tabular}{|c|c|c|c|c|c|c|}
\hline & $\mathrm{x}_{1}$ & $\mathrm{x}_{2}$ & $\mathrm{x}_{3}$ & $\mathrm{x}_{4}$ & $\mathrm{x}_{5}$ & $\mathrm{x}_{6}$ \\
\hline Etalon point & 4,224231 & 5,299793 & 8,694921 & 4,224231 & 4,807692 & 3,428571 \\
\hline
\end{tabular}


Vol. 1, No. 2, 2015

$$
C_{o i}=\sqrt{\sum_{j=1}^{m}\left(z_{i j}-z_{o j}\right)^{2}}
$$

where $z_{i j}$ - standardize value of $j$-th indicator for $i$-th object;

$z_{o j}$ - standardize value of $j$-th indicator for the etalon

The results of calculation of euclidean distance for the enterprises are presented in table 4.

Table 4

\section{Euclidean distance}

\begin{tabular}{|l|c|}
\hline \multicolumn{1}{|c|}{ Enterprise } & Indicator \\
\hline $\begin{array}{l}\text { Public Joint-Stock Company "Kharkov } \\
\text { Machine-Building Plant "Svet Shakhtyora }\end{array}$ & 12,86562901 \\
\hline State Enterprise Plant "Electrotyazhmash" & 10,53582229 \\
\hline Public Joint Stock Company Yuzhcable Works & 7,679547844 \\
\hline Public Joint-Stock Company "Electromashina" & 12,66742943 \\
\hline Public Stock Company Frunze Plant & 12,65219426 \\
\hline $\begin{array}{l}\text { Public Joint-Stock Company "Kharkov Trac S. } \\
\text { Ordzhonikidze Plant" }\end{array}$ & 12,26476324 \\
\hline "Turboatom" Public Joint Stock Company & 10,89409639 \\
\hline $\begin{array}{l}\text { Public Joint-Stock Company "Kharkov Bearing } \\
\text { Plant" }\end{array}$ & 10,32356567 \\
\hline $\begin{array}{l}\text { State Research and Development Enterprise } \\
\text { "Obiedinenie Communar" }\end{array}$ & 12,6005553 \\
\hline $\begin{array}{l}\text { State Enterprise "Kharkov Machine Building } \\
\text { Plant "FED" }\end{array}$ & 12,58922216 \\
\hline
\end{tabular}

The following step is determination of the value of the taxonomic indicator of development which is calculated according to the formula (Litvinova 2012):

$$
\begin{aligned}
& K_{i}=1-d_{i} \\
& \text { where } K_{i} \in[0.1] \\
& d_{i}=\frac{C_{i o}}{C_{o}} \\
& C_{o}=\overline{C_{o}}+2 S_{o} \\
& S_{o}=\sqrt{\frac{1}{m} \sum\left(C_{i o}-\overline{C_{o}}\right)^{2}}
\end{aligned}
$$

The obtained results of calculation are presented in table 5 .

Consequently according to the data of the conducted analysis it may be concluded that Public Joint-Stock Company "Kharkov Machine-Building Plant "Svet Shakhtyora" is the enterprise with the high level of criteria of innovative activity since the value of the taxonomic indicator thereof is 0,878 that is close to 1 . This also evidences that among the studied enterprises the most active researches of the innovative products are conducted on this plant as well as the innovative technologies are applied and the substantial costs are expended for the research scientific and the experimental development works.

Public Joint Stock Company Yuzhcable Works has the lowest value of the criteria of innovative development of 0,524 that confirms the lack of the innovative activity level of the enterprise and necessity of amelioration thereof. The appliance of the new technologies is the necessary
Table 5

Value of the criteria of the level of development

\begin{tabular}{|l|c|}
\hline \multicolumn{1}{|c|}{ Enterprise } & Value of the criteria \\
\hline $\begin{array}{l}\text { Public Joint-Stock Company "Kharkov } \\
\text { Machine-Building Plant "Svet Shakhtyora }\end{array}$ & 0,878 \\
\hline State Enterprise Plant "Electrotyazhmash" & 0,719 \\
\hline $\begin{array}{l}\text { Public Joint Stock Company Yuzhcable } \\
\text { Works }\end{array}$ & 0,524 \\
\hline $\begin{array}{l}\text { Public Joint-Stock Company } \\
\text { "Electromashina" }\end{array}$ & 0,864 \\
\hline Public Stock Company Frunze Plant & 0,863 \\
\hline $\begin{array}{l}\text { Public Joint-Stock Company "Kharkov Trac } \\
\text { S. Ordzhonikidze Plant" }\end{array}$ & 0,837 \\
\hline "Turboatom" Public Joint Stock Company & 0,743 \\
\hline $\begin{array}{l}\text { Public Joint-Stock Company "Kharkov } \\
\text { Bearing Plant" }\end{array}$ & 0,704 \\
\hline $\begin{array}{l}\text { State Research and Development } \\
\text { Enterprise "Obiedinenie Communar" }\end{array}$ & 0,860 \\
\hline $\begin{array}{l}\text { State Enterprise "Kharkov Machine } \\
\text { Building Plant "FED" }\end{array}$ & 0,859 \\
\hline
\end{tabular}

condition for amelioration of the value of the taxonomic indicator.

On the basis of the obtained estimation the studied enterprises are ranged depending on the level of innovative development and the results are presented in table 6 .

Table 6

Rating of the enterprises of the machine building industry of Kharkov region according to the indicator of the level of innovative development

\begin{tabular}{|l|c|c|}
\hline \multicolumn{1}{|c|}{ Enterprise } & $\begin{array}{c}\text { Indicator of the } \\
\text { level of innovative } \\
\text { development }\end{array}$ & $\begin{array}{c}\text { Rating } \\
\text { position }\end{array}$ \\
\hline $\begin{array}{l}\text { Public Joint-Stock Company } \\
\text { "Kharkov Machine-Building Plant } \\
\text { "Svet Shakhtyora }\end{array}$ & 0,878 & 1 \\
\hline $\begin{array}{l}\text { Public Joint-Stock Company } \\
\text { "Electromashina" }\end{array}$ & 0,864 & 2 \\
\hline Public Stock Company Frunze Plant & 0,863 & 3 \\
\hline $\begin{array}{l}\text { State Research and Development } \\
\text { Enterprise "Obiedinenie Communar" }\end{array}$ & 0,860 & 4 \\
\hline $\begin{array}{l}\text { State Enterprise "Kharkov Machine } \\
\text { Building Plant "FED" }\end{array}$ & 0,859 & 5 \\
\hline $\begin{array}{l}\text { Public Joint-Stock Company"Kharkov } \\
\text { Trac S. Ordzhonikidze Plant" }\end{array}$ & 0,837 & 6 \\
\hline $\begin{array}{l}\text { "Turboatom" Public Joint Stock } \\
\text { Company }\end{array}$ & 0,743 & 7 \\
\hline $\begin{array}{l}\text { State Enterprise Plant } \\
\text { "Electrotyazhmash" }\end{array}$ & 0,719 & 8 \\
\hline $\begin{array}{l}\text { Public Joint-Stock Company } \\
\text { "Kharkov Bearing Plant" }\end{array}$ & 0,704 & 9 \\
\hline $\begin{array}{l}\text { Public Joint Stock Company } \\
\text { Yuzhcable Works }\end{array}$ & 0,524 & 10 \\
\hline
\end{tabular}

According to the data of table 6 all the studied objects are sorted into the rate scale depending on thelevel ofinnovative development. Thus the first three positions are occupied by the following enterprises: Public Joint-Stock Company 
"Kharkov Machine-Building Plant "Svet Shakhtyora, Public Joint-Stock Company "Electromashina" and Public Stock Company Frunze Plant having the taxonomic indicators 0,$878 ; 0,864$ and 0,863 correspondingly. The last three positions with the results of 0,$719 ; 0,704$ and 0,524 are occupied by the following enterprises: State Enterprise Plant "Electrotyazhmash", Public Joint-Stock Company "Kharkov Bearing Plant" and Public Joint Stock Company Yuzhcable Works. Still it should be noted that despite the rating positions of the studied enterprises nine of ten among them have the taxonomic indicator close to 1 that evidences the innovative activity thereof and drive to innovative development.

\section{Conclusion}

On the basis of the aforementioned it may be concluded that the guarantee of the welfare of any country is innovative way of the development implementation of which depends directly on research, creation and appliance of the innovations on the industrial enterprises. Therefore it is expedient to research the status and the tendencies of the development of innovative activity of the industrial enterprises and to explore the reserves of amelioration of the level of innovative development thereof. The results of the conducted taxonomic analysis of the certain enterprises of the machinery of Ukraine in Kharkov region show that the criteria of the level of innovative development thereof ranges from 0,524 to 0,878 . This evidences that nevertheless the enterprises declare the orientation on innovative development in fact not all of the studied enterprises are innovatively active on all criteria. However the most of them have the value of the taxonomic indicator close to one that confirms the orientation on the way of innovative development thereof.

\section{References}

The State Statistics Service of Ukraine (2014). Reading allowed: Annual review and summary of statistics data of Ukraine 2014. Retrieved from: http:/ /www.ukrstat.gov.ua

Litvinova, V. (2012). Taxonomic analysis as a method of estimating the competitiveness of products. Electronic scientific specialized journal "Economic. Management. Innovations". [Electronic resource]. - Retrieved from: http://nbuv.gov.ua/j-pdf/eui_2012_1_29.pdf

Ponomarenko, V.S. and Maliarets, L.M. (2009). The analysis of data in studies of socio-economic systems: monograph - Kharkiv, Ukraine, INZHEK publishing house, $432 \mathrm{p}$.

Senichkina, O.E. (2014). Detection of effectiveness factors impact on innovative activity of industrial enterprises. Scientific and Production journal "Innovative economy», Vol. 51 issue 2, p. 71-76.

\section{Екатерина КОЛЕДИНА}

\section{ИССЛЕДОВАНИЕ УРОВНЯ ИННОВАЦИОННОГО РАЗВИТИЯ МАШИНОСТРОИТЕЛЬНЫХ ПРЕДПРИЯТИЙ УКРАИНЫ В ХАРЬКОВСКОЙ ОБЛАСТИ}

Аннотация. В современном мире развития науки и новых технологий перед всеми странами, включая Украину, стоит задача переориентации на инновационный путь развития. Уровень инновационности государства зависит от развития предприятий в этом направлении, поскольку именно промышленные предприятия способны стимулировать инновационный прогресс и выступают мультипликатором других отраслей. Поэтому целесообразным является техническое перевооружение промышленности страны и поддержка именно наукоемких отраслей производства. В связи с этим чель данной работы заключается в исследовании и оценке влияния показателей инновационной деятельности промышленных предприятий на уровень их инновационного развития. Для достижения поставленной цели объектами исследования стали показатели инновационной деятельности ведущих машиностроительных предприятий Украины в Харьковской области. Данные предприятия являются инновационно активными в Харьковском регионе по показателям своей деятельности. Для анализа были выбраны следующие показатели инновационной деятельности предприятий: объем реализованной инновационной продукции; расходы на инновации; наукоемкость инновационной продукции; доля исследуемых предприятий в общем объеме реализованной продукции по области; количество новых технологических процессов; количество новых инновационных видов продукции. Избранные показатели являются важными для предприятия с точки зрения инновационной деятельности и при изменении оказывают существенное влияние на его развитие и стабильность.

Методика. Для исследования уровня инновационного развития машиностроительных предприятий Украины в Харьковской области нами было предложено метод таксономического анализа, алгоритм которого состоит из следующих семи этапов:
1) формирование матрицы исходных данных;
2) стандартизация исходных данных;
3) дифференциация признаков на стимуляторы и дестимуляторы; 
Vol. 1, No. 2, 2015

4) построение эталона;

5) определение расстояния между объектами и эталоном;

6) расчет показателя уровня развития;

7) составление рейтинга предприятий по уровню инновационного развития.

Результаты. Результаты проведенного таксономического анализа отдельных предприятий машиностроения Харьковской области (Украина) показали, что показатель уровня развития на исследуемых предприятиях колеблется в пределах 0,524-0,878. Полученный результат свидетельствует о том, что хотя предприятия и декларируют ориентацию на инновационное развитие, не все из ряда рассмотренных предприятий действительно являются инновационно активными по всем показателям. Однако большинство из них все же имеет значение таксономического показателя, близкого к единице, что говорит об их ориентации на путь инновационного развития. Значение/оригинальность. Полученные в результате расчета и анализа данные способствуют улучшению понимания взаимосвязи между показателями инновационной деятельности предприятий и уровнем их инновационного развития. Это позволит предприятиям в дальнейшем корректировать свою инновационную деятельность в зависимости от сложившейся ситуации и принимать эффективные управленческие решения, ориентированные на путь инновационного развития. 